Danuta Janicka

Uniwersytet Mikołaja Kopernika, Toruń

\title{
Jurysdykcja państwa niemieckiego w warunkach wielokulturowego społeczeństwa - kilka wybranych przykładów ze szczególnym uwzględnieniem orzecznictwa administracyjnego i konstytucyjnego
}

DOI: http://dx.doi.org/10.12775/SIT.2014.026

\section{Uwagi wstępne - wielokulturowość w Niemczech}

Niemcy są społeczeństwem wielokulturowym - mieszkają tu grupy o różnym pochodzeniu, religii czy wyznawanych wartościach. Według danych Federalnego Urzędu Statystycznego $z$ Wiesbaden wśród 80,5 mln mieszkańców RFN co 12 osoba jest obcokrajowcem. Pod koniec 2012 r. w Niemczech mieszkało 7,2 mln cudzoziemców ludzi nieposiadających niemieckiego paszportu. Wśród nich zdecydowany prym od lat wiodą Turcy, których jest 1,6 mln (nie licząc obywateli niemieckich pochodzenia tureckiego); na drugim miejscu od niedawna plasują się Polacy, których w RFN przebywa około 532 tys. Nasi rodacy nieznacznie wyprzedzają Włochów (529 tys.). Dalej za nimi są Grecy (298 tys.) i Chorwaci (225 tys.). Znaczące skupiska tworzą jeszcze Rosjanie (202 tys.), Austriacy (176 tys.) i Bośniacy (155 tys.). Liczbę mieszkańców przybyłych do Niemiec 
z Afryki szacuje się na 288 tys., natomiast z Ameryki - na 232 tys. Przybysze $z$ całej Azji stanowią około 897 tys. mieszkańców. W wielkich miastach, a zwłaszcza Berlinie, Hamburgu, Kolonii, liczba cudzoziemców sięga kilkunastu procent; we Frankfurcie nad Menem co czwarty mieszkaniec nie ma niemieckiego paszportu ${ }^{1}$.

Należy przypomnieć, że na przełomie lat 50. i 60. XX w. Niemcy Zachodnie, w związku z gwałtownym rozwojem gospodarki i brakiem rąk do pracy, zaczęły masowo sprowadzać robotników z innych krajów, tzw. gastarbeiterów (niem. Gastarbeiter). Pochodzili oni głównie z Hiszpanii, Włoch, Turcji, Grecji i Jugosławii. Władze niemieckie zakładały pierwotnie, że gastarbeiterzy będą pracować w niemieckich fabrykach tylko przez pewien czas. Nie zadbano o dostateczne mechanizmy rozwiązywania problemów imigrantów, zwłaszcza ich integrację ze społeczeństwem zachodnioniemieckim. Tymczasem w latach 60., szczególnie po wybudowaniu muru berlińskiego, liczba gastarbeiterów wzrosła lawinowo - z niespełna 300 tys. w 1960 r. do ponad 2,5 mln w 1973 r. Imigrację zahamował dopiero kryzys naftowy z 1973 r. Po kryzysie gastarbeiterzy nie tylko pozostali w państwie zachodnioniemieckim, lecz także sprowadzili swoje rodziny. Jednocześnie zaczęła rosnąć liczba azylantów. Państwo zachodnioniemieckie nie było na to przygotowane. Niemcy nigdy w swej historii nie doświadczyły obecności tak wielu imigrantów przybyłych w tak krótkim czasie.

Poważnym problemem ludności napływowej, wynikającym także z niewłaściwej polityki imigracyjnej, była i jest tzw. imigracja wewnętrzna - dorastanie dzieci w społecznościach, które nie są w zasadzie niemieckie. Imigracja wewnętrzna łączy się z gorszą sytuacją socjalną i materialną. W większych miastach powstają swoiste getta obcokrajowców, a oni sami pozbawieni równych szans w edukacji, dyskryminowani na rynku pracy, dotknięci bezrobociem - często wchodzą w świat przestępczości. Wśród Niemców widoczne są

${ }^{1}$ Dane zaczerpnięte $z$ oficjalnej strony internetowej Federalnego Urzędu Statystycznego (Statistisches Bundesamt) w Wiesbaden: https://www.destatis. de/DE/ZahlenFakten/GesellschaftStaat/Bevoelkerung/MigrationIntegration/ AuslaendischeBevolkerung/Tabellen/Geschlecht.html (dostęp: 28 grudnia 2013 r.). 
tymczasem nastroje rasistowskie, czego wyrazem jest m.in. wzrost popularności skrajnie prawicowej, neonazistowskiej Narodowo-Demokratycznej Partii Niemiec ${ }^{2}$.

Największą grupę etniczno-religijną na terytorium RFN stanowią Turcy. Obecnie w Niemczech mieszka około 2,8 mln Turków (3,4\% mieszkańców) - obywateli pochodzenia tureckiego i Turków bez niemieckiego paszportu. Nie stanowią oni homogenicznej grupy etniczno-religijnej, ponieważ część z nich to Kurdowie. Największe skupiska tureckie są obecne w Berlinie, Hamburgu, a także w landach Nadrenia Północna-Westfalia oraz Badenia-Wirtembergia.

Jednym $z$ głównych problemów imigrantów tureckich jest słaba znajomość języka niemieckiego. Wynika ona $z$ braku klas dwujęzycznych, $z$ wyjątkiem Berlina. W szkołach prowadzona jest jedynie, z inicjatywy związków muzułmańskich, nauka religii islamskiej. Jak wiadomo, muzułmanie nie tworzą zorganizowanego kościoła, takiego jak posiadające osobowość prawną Kościoły katolicki czy protestancki. W RFN działają natomiast setki organizacji muzułmańskich o charakterze społeczno-politycznym, często powiązanych z partiami politycznymi w Turcji. Legalnie działają też liczne organizacje społeczno-kulturalne oraz religijne, nierzadko nacechowane nacjonalistycznie ${ }^{3}$.

Muzułmańscy imigranci najczęściej korzystają z własnych sądów. W miastach, gdzie ich społeczność jest największa, m.in. w Berlinie, Essen, Bremie, działają liczni sędziowie pokoju, oczywiście bez prawniczego wykształcenia, którzy na podstawie reguł szariatu rozpoznają sprawy cywilne i karne, także o najcięższe przestępstwa. Ich orzecznictwo przypomina polubowne (ugodowe) załatwianie spraw, a szacunki wskazują, że 90\% sporów między muzułma-

2 Narodowo-Demokratyczna Partia Niemiec (niem. NPD), założona w 1964 r., jest partią skrajnej prawicy, nacjonalistyczną i rewanżystowską. Działa legalnie, mimo podjętej przed 10 laty próby jej delegalizacji (Federalny Trybunał Konstytucyjny w 2003 r. odrzucił wniosek w tej sprawie z powodów formalnych). W grudniu 2013 r. ponownie wszczęto postępowanie przed Trybunałem o delegalizację NPD.

${ }^{3}$ Po atakach terrorystycznych z 11 września 2001 r. swoboda działalności organizacji i stowarzyszeń została ograniczona, o czym mowa dalej. 
nami trafia przed oblicze tych cieszących się wielkim autorytetem islamskich sędziów ${ }^{4}$.

Publiczna debata nad problemami „społeczeństwa wielokulturowego" (niem. multikulturelle Gesellschaft) nasiliła się w Niemczech od lat 80. XX w. ${ }^{5}$ Rzecznicy wielokulturowości (niem. Multikulturalismus, Multi-Kulti, Multikulti) postulowali i nadal żądają od państwa pełnej akceptacji oraz ochrony różnic kulturowych. Nie dopuszczają jakiegokolwiek nacisku w kierunku asymilacji różnych grup etnicznych, zwłaszcza ze strony władz państwowych. Dawniej w Republice Federalnej Niemiec wyrażano poglądy, że „kolorowe Niemcy” (niem. buntes Deutschland) są rezultatem wzorowej integracji obcokrajowców. Opinia ta już dawno straciła na aktualności. Od dłuższego czasu proces włączania cudzoziemców w społeczeństwo niemieckie jest przedmiotem ostrych dyskusji oraz nieustających zabiegów władz federalnych i krajowych, częściowo nieudolnych. Tymczasem kwestia sposobu rozumienia wielokulturowości jest kluczową debatą na temat niemieckiej tożsamości jako takiej ${ }^{6}$.

\section{Orzecznictwo konstytucyjne}

Federalny Trybunał Konstytucyjny (dalej: FTK) działa w Republice Federalnej Niemiec od 1951 r. ${ }^{7}$ Jego ustrój i funkcjonowanie określa konstytucja oraz - szczegółowo - ustawa o Federalnym Trybunale Konstytucyjnym z 1951 r., którą uzupełnia regulamin FTK ${ }^{8}$.

${ }^{4}$ B.T. Wieliński, Islamscy sędziowie w Niemczech, „Gazeta Wyborcza” 2 września 2011, http://m.wyborcza.pl/wyborcza/1, 105226, 10218835, Islamscy_ sedziowie_w_Niemczech.html (dostęp: 16 grudnia 2013 r.).

${ }^{5}$ K. Gelles, M. Kozerski, Społeczeństwo wielokulturowe $w$ Niemczech $w$ opinii przedstawicieli niemieckich partii politycznych, „Niemcoznawstwo” 2008, nr 16, s. $133-155$.

${ }^{6}$ P. Buras, $Z$ islamem krzyż pański, „Gazeta Wyborcza” 30-31 maja 2009, s. $19-20$.

${ }^{7}$ L. Garlicki, Federalny Trybunał Konstytucyjny $w$ Republice Federalnej Niemiec, w: Sądy konstytucyjne w Europie, t. 1: Austria, Francja, Niemcy, Włochy, red. J. Trzciński, Warszawa 1996, s. 135-148.

8 Zob.: ustawę Gesetz über das Bundesverfassungsgericht vom 12. März 1951 (BGBl. I, 243) w brzmieniu z 11 sierpnia 1993 r. (BGBl. I, 1473), ostatnio 
Najczęstszym przedmiotem działalności FTK są w praktyce skargi konstytucyjne (niem. Verfassungsbeschwerden) ${ }^{9}$. W sumie do końca 2013 r. FTK rozpoznał ich około 200 tys. ${ }^{10}$ Należy jednak zaznaczyć, że skala spraw załatwionych pozytywnie dla skarżących kształtuje się od dziesięcioleci na niskim poziomie i wynosi zaledwie około $2,5 \%{ }^{11}$.

Skargi konstytucyjne służą generalnie ochronie praw podstawowych. Warto w tym miejscu przypomnieć, że niemiecki ustrojodawca uczynił $z$ praw podstawowych uprawnienia jednostki chronione bezpośrednio prawem, umieścił je w pierwszym rozdziale konstytucji ${ }^{12}$

zmienioną ustawą z 29 lipca 2009 r. (BGBl. I, 2346); regulamin Bekanntmachung der Geschäftsordnung des Bundesverfassungsgerichts vom 2. September 1975 (BGBl. I, 2515) w brzmieniu z 15 grudnia 1986 r. (BGBl. I, 2529), ostatnio zmieniony obwieszczeniem z 7 stycznia 2002 r. (BGBl. I, 1171). Kilkanaście lat temu ukazało się polskie wydanie ustawy i regulaminu: Sądy konstytucyjne $w$ Europie, s. 152-207. Niemiecka konstytucja poświęca Trybunałowi zaledwie dwa przepisy: art. 93-94. Co do ustawy zasadniczej zob. przypis 12 .

9 Skarga konstytucyjna została wprowadzona do porządku prawnego RFN dopiero w 1969 r. Wcześniej osoba, której prawo podstawowe naruszono, mogła wnieść skargę do sądu powszechnego. Obok skarg konstytucyjnych do Trybunału należy m.in. tzw. kontrola norm niem. Normenkontrolle), przeprowadzana w trybie kontroli abstrakcyjnej (rozstrzyganie, czy dany akt prawny jest zgodny z konstytucją) lub konkretnej (orzekanie, czy zastosowano prawo zgodnie $z$ konstytucją). Zob.: B. Banaszak, Sąownictwo konstytucyjne a ochrona podstawowych praw obywatelskich. RFN, Austria, Szwajcaria, Wrocław 1990; M. Derlatka, Skarga konstytucyjna w Niemczech, Warszawa 2009.

${ }^{10}$ Do lat 70 . XX w. liczba skarg nie przekraczała 1500 rocznie; lata 80. przyniosły wzrost do ponad 3000 skarg rocznie; po zjednoczeniu Niemiec zaczęło napływać 4-5 tys. spraw każdego roku; obecnie jest ich ponad 6 tys. Skargi konstytucyjne stanowią 97\% wszystkich spraw wniesionych do Trybunału. Szczegółowe dane i wykresy zawiera http://www.bundesverfassungsgericht.de/organisation/gb2012/A-I-2.html (dostęp: 13 lipca 2013 r.). Zob. też B. Nita, Skarga konstytucyjna $w$ Republice Federalnej Niemiec ( $w$ świetle danych statystycznych oraz orzecznictwa niemieckiego Federalnego Trybunału Konstytucyjnego), „Przegląd Sejmowy” 2001, nr 2, s. 58-70.

${ }_{11}$ Taki rezultat świadczy o dobrym funkcjonowaniu niemieckiej legislatywy i egzekutywy, a także judykatury - zob. H.J. Papier, Das Bundesverfassungsgericht als Anreger und Hüter der Verfassungsentwicklung, w: Festschrift für Winfried Hassemer, red. F. Herzog, U. Neumann, Heidelberg 2010, s. 186.

${ }^{12}$ Zob. tekst konstytucji w języku polskim w ostatnich wydaniach książkowych: B. Banaszak, A. Malicka, Konstytucja Niemiec, Warszawa 2008; Ustawa 
oraz wyraźnie zagwarantował, że wiążą one wszystkie władze państwowe $^{13}$. Właściwe prawa i wolności (osobiste, polityczne i inne) poprzedza konstytucyjna zasada równości, której towarzyszy zakaz dyskryminacji, m.in. z powodu pochodzenia, rasy, języka, ojczyzny, religii ${ }^{14}$.

Orzecznictwo konstytucyjne, także w zakresie praw podstawowych, jest blisko związane $z$ polityką. Współcześnie widoczna jest wręcz tendencja oczekiwania, a nawet żądania przez polityków, aby FTK wydał stosowne orzeczenie. Trudno byłoby przecenić rolę niemieckiego FTK w zakresie praw podstawowych - od lat gwarantuje im nie tylko ochronę przed naruszeniami ze strony organów państwowych, ale także je kształtuje, tworząc nowe prawa i wolności obywatelskie, a ponadto nadaje prawom podstawowym charakter gwarancji instytucjonalnych ${ }^{15}$. Warto jeszcze dodać, że ochrona

zasadnicza (konstytucja) Republiki Federalnej Niemiec z 23 maja 1949 r.: wersja niemiecka i polska $z$ uwzględnieniem wszystkich kolejnych zmian, red. L. Janicki, tłum. J. Koprucka-Purolowa, B. Demby, Poznań 2007. Por.: edycję internetową Ustawa zasadnicza Republiki Federalnej Niemiec z 23 maja 1949, tłum. E. Schwierskott-Matheson, http://www.de-iure-pl.org/gesetze/recht/ verfassung/text/1,1,741,DE,PL,.html (dostęp: 27 grudnia 2013 r.); niemieckie wydanie urzędowe Grundgesetz für die Bundesrepublik Deutschland vom 23. Mai 1949 (BGB1. 1), zuletzt geändert durch das Gesetz vom 11. Juli 2012 (BGBl. I, 1478), http://www.bundestag.de/bundestag/aufgaben/rechtsgrundlagen/grundgesetz/gg.html (dostęp: 27 grudnia 2013 r.).

${ }^{13}$ Art. 1 ust. 3 ustawy zasadniczej: „Poniższe prawa podstawowe wiążą ustawodawstwo, władzę wykonawczą i wymiar sprawiedliwości jako prawo bezpośrednio wiążące”. Podstawą tych rozwiązań jest fundamentalny art. 1 ust. 1 wskazujący na nienaruszalność godności człowieka, oraz tzw. gwarancja wieczystości, zapisana w art. 79 ust. 3, bezwzględnie chroniąca pewne wartości - nawet w wypadku zmiany konstytucji.

${ }^{14}$ Niemiecki ustrojodawca gwarantuje równość wszystkich ludzi wobec prawa oraz proklamuje zasadę równouprawnienia kobiet i mężczyzn. Jednocześnie zakazuje dyskryminacji. Wśród kryteriów niedozwolonej dyskryminacji wylicza m.in. płeć, ród, pochodzenie, rasę, język, ojczyznę, wiarę, poglądy religijne i polityczne, niepełnosprawność.

${ }^{15}$ H.J. Papier, op.cit., s. 192-193. Autor ten wskazuje (ibidem, s. 197), że gdy brakuje porozumienia głównych sił politycznych, Trybunał staje się mediatorem i rzeczoznawcą (niem. Schlichtungs- und Gutachterinstanz). Zob.: P. Czarny, Federalny Trybunał Konstytucyjny i ewolucja jego polityczno-ustrojowego znaczenia $w$ Niemczech i Europie, „Przegląd Sejmowy” 2009, nr 6, s. 107-124; 
praw podstawowych jest w Niemczech rozbudowana i udzielana nie tylko przez FTK, lecz także przez sądy konstytucyjne poszczególnych krajów (landów), a ponadto przez trybunały strasburski i luksemburski ${ }^{16}$.

\section{Orzecznictwo administracyjne}

Sądy administracyjne mają w Niemczech strukturę trójszczeblową, na którą składają się sądy administracyjne, wyższe sądy administracyjne oraz Federalny Sąd Administracyjny ${ }^{17}$. Wszystkie działają na podstawie wielokrotnie nowelizowanych ustaw - ordynacji z 1960 r. ${ }^{18}$ oraz ustawy z 1976 r. ${ }^{19}$ Ich głównym celem jest oczywiście ochrona obywateli przez niezgodnymi z prawem działaniami władz publicznych $^{20}$.

Wyższe sądy administracyjne (niem. Oberverwaltungsgerichte) zajmują się m.in. kontrolą zgodności norm prawnych $\mathrm{z}$ prawem krajowym, którą - co charakterystyczne - wykonują niezależnie od analogicznej działalności FTK w zakresie rozstrzygania o zgod-

B. Banaszak, M. Bernaczyk, Aktywizm sędziowski we wspótczesnym państwie demokratycznym, Warszawa 2012, s. 186-191.

${ }^{16}$ Jeżeli naruszono ustawę zasadniczą, Niemcy szukają ochrony w Federalnym Trybunale Konstytucyjnym. Jeżeli doszło do naruszenia konstytucji krajowej, sprawą może zająć się sąd konstytucyjny danego landu. Droga ta jest chętnie wykorzystywana przez Niemców, ponieważ niełatwo uzyskać „korzystne” dla siebie orzeczenie Trybunału z Karlsruhe, o czym już wspomniano. W wypadku naruszenia Europejskiej konwencji praw człowieka ochrony można szukać w Strassburgu - w Europejskim Trybunale Praw Człowieka. Jeśli naruszono prawo wspólnotowe, przysługuje odwołanie do Trybunału Sprawiedliwości Unii Europejskiej w Luksemburgu.

17 D. Janicka, Ustawa zasadnicza $w$ praktyce Republiki Federalnej Niemiec (1949-1989), Toruń 2009, s. 266.; B. Banaszak, Ł. Żukowski, System środków ochrony praw podstawowych w RFN, „Przegląd Sejmowy” 2009, nr 6, s. $49-50$.

${ }^{18}$ Verwaltungsgerichtsordnung vom 21. Januar 1960 z późn. zm. Tekst jednolity z 1991 r.: BGBl. I, 686.

19 Verwaltungsverfahrensgesetz vom 25. Mai 1976 z późn. zm. Tekst jednolity z 2004 r.: BGBl. I, 718.

${ }^{20}$ D. Janicka, op.cit., s. 266-267. 
ności aktów prawnych z konstytucją. Do sądów administracyjnych należy jednak badanie przepisów niższego rzędu, w szczególności rozporządzeń wykonawczych (niem. Rechtsverordnungen). Jeżeli sąd administracyjny stwierdzi, że przepis rozporządzenia jest niezgodny z prawem krajowym, uchyla go ${ }^{21}$.

Inną ważną domeną wyższych sądów administracyjnych jest badanie wydanych przez organy administracyjne zakazów działalności stowarzyszeń i innych organizacji, także religijnych. Warto zaznaczyć, że do 2001 r. związki religijne były wyłączone spod zakresu działania ustawy o stowarzyszeniach ${ }^{22}$. Jednak po zamachach terrorystycznych z 11 września 2001 r. ich status zmienił się - uchwalony w listopadzie 2002 r. pakiet ustaw antyterrorystycznych ${ }^{23}$ otworzył możliwość delegalizacji organizacji religijnych ${ }^{24}$, tym samym rozszerzając zadania wyższych sądów administracyjnych.

\section{Zakazy działalności stowarzyszeń}

Jak już wspomniano, zamachy z 11 września spowodowały w Niemczech wprowadzenie pakietu ustaw antyterrorystycznych. Ustawa antyterrorystyczna z 2002 r. ograniczyła dotychczasową autonomię stowarzyszeń religijnych i światopoglądowych, umożliwiając ich delegalizację $e^{25}$. Do wydania odpowiedniego zakazu zostali uprawnieni

${ }^{21}$ Verwaltungsgerichtsordnung, § 47 ust. 1 pkt 2.

${ }^{22}$ Gesetz zur Regelung des öffentlichen Vereinsrechts (Vereinsgesetz) vom 5. August 1964 (BGBl. I, 593). Po zamachach terrorystycznych z 11 września 2001 r. ustawa została zmieniona już 4 grudnia 2001 r. (BGBl I, 3319) przez zniesienie dotychczasowego tzw. przywileju religijnego (niem. Religionsprivileg).

${ }^{23}$ Gesetz zur Bekämpfung des internationalen Terrorismus (Terrorismusbekämpfungsgesetz) vom 9. Januar 2002 (BGB1. I, 361). Ustawa weszła w życie z mocą wsteczną od dnia 1 stycznia 2002 r. i była początkowo przewidywana na pięć lat, a następnie została przedłużona i nadal obowiązuje.

${ }^{24}$ Przepis $\S 2$ Vereinsgesetz uznał za stowarzyszenie (niem. Verein) każde zrzeszenie (niem. Vereinigung), w którym dobrowolnie i na dłuższy czas jednoczy się wiele osób fizycznych lub prawnych dla wspólnego celu, podporządkowując się jego organizacji.

${ }^{25} \mathrm{Na}$ temat środków przewidzianych przez ustawę antyterrorystyczną z 9 stycznia 2002 r. zob. E. Denninger, Freiheit durch Sicherheit? Anmerkungen 
Federalny Minister Spraw Wewnętrznych oraz krajowi ministrowie spraw wewnętrznych. Podstawy zakazania działalności organizacji społecznych, religijnych itp. określają ustawa zasadnicza ${ }^{26}$ oraz ustawa o stowarzyszeniach ${ }^{27}$, wskazując na sprzeczne $\mathrm{z}$ prawem karnym, porządkiem konstytucyjnym oraz zasadą pokojowego współistnienia narodów - cele stowarzyszenia. Na decyzję ministra o zakazie działalności organizacji przysługuje skarga do sądu administracyjnego, zarzucająca decyzji ministerialnej niezgodność Z prawem ${ }^{28}$.

W ciągu ostatniej dekady zakazy aktywności dotknęły liczne organizacje, zwłaszcza muzułmańskie ${ }^{29}$. Już pod koniec 2001 r. zakazano działalności organizacji Kalifatsstaat (arab. Hilafet Devleti), powstałej w $1994 \mathrm{r}^{30} \mathrm{Na}$ czele tego islamskiego związku stał przewodniczący, zwany kalifem, od którego wzięła się też nazwa organizacji. Przewodniczący, Metin Kaplan, stawał w Niemczech kilkakrotnie przed sądami, najpierw $z$ powodu nienależnego pobrania świadczeń społecznych, następnie $z$ powodu publicznego wzywania do popełnienia przestępstwa. Po odbyciu kilkuletniej kary pozbawienia wolności oraz dalszych, wielomiesięcznych procedurach Kaplan został ostatecznie wydalony do Turcji, gdzie w 2005 r. stanął przed sądem pod zarzutem usiłowania obalenia przemocą porządku konstytucyjnego i skazany na dożywotnie pozbawienie wolności ${ }^{31}$. Wydana w 2001 r. decyzja o zakazie działalności Kalifatsstaat została zaskarżona do Federalnego Sądu Administracyjnego, który

zum Terrorismusbekämpfungsgesetz, 2002, http://www.bpb.de/publikationen/32OUOD,0,Freiheit_durch_Sicherheit.html (dostęp: 16 grudnia 2013 r.).

${ }^{26}$ Art. 9 ust. 2 ustawy zasadniczej.

$27 \S 3$ ust. 1 Vereinsgesetz.

${ }^{28} \S 6$ Vereinsgesetz.

${ }^{29}$ P. Sus, Społeczno-polityczne determinanty funkcjonowania Turków $w$ RFN, „Niemcoznawstwo” 2009, nr 17, s. 197-220.

${ }^{30}$ Obwieszczenie Federalnego Ministra Spraw Wewnętrznych z 8 grudnia 2001 r. jest dostępne w internecie: http://www.documentarchiv.de/brd/2001/ verbot-kalifatsstaat.html (dostęp: 16 grudnia 2013 r.).

${ }^{31}$ Der „Kalif von Köln“ bleibt lebenslang in Haft, „Die Welt“ 15 października 2008; http://www.welt.de/politik/article2581307/Der-Kalif-von-Koeln-bleibtlebenslang-in-Haft.html (dostęp: 16 grudnia 2013 r.); http://de.wikipedia.org/ wiki/Metin_Kaplan (dostęp: 16 grudnia 2013 r.). 
w 2002 r. ją podtrzymał ${ }^{32}$. Kolejna skarga trafiła zatem do FTK, lecz ten w 2003 r. także uznał, że zakaz był zgodny $z$ prawem ${ }^{33}$.

Głośnym echem odbiło się w Niemczech orzeczenie Federalnego Sądu Administracyjnego z 2004 r., w którym znalazło się obszerne wyjaśnienie, kiedy stowarzyszenie godzi w zasadę porozumienia między narodami ${ }^{34}$. Sąd administracyjny rozpatrywał wydany przez Federalnego Ministra Spraw Wewnętrznych w 2002 r. zakaz działalności organizacji Al-Aqsa, która finansowała palestyński związek zamachowców samobójców Märtyrer, powiązany z Hamasem ${ }^{35}$. Sąd uznał, że oskarżona organizacja Al-Aqsa godziła w zasadę pokojowego współistnienia narodów, ponieważ wspierała materialnie przez długi czas, celowo i w poważnym zakresie ugrupowanie, które stosowało przemoc w stosunkach między narodami, godząc w pokojowe współistnienie narodów żydowskiego i palestyńskiego.

Inne stanowisko zajął Federalny Sąd Administracyjny w sprawie członkostwa w radykalnej islamskiej organizacji Millî Görüş (dosł. Narodowy Punkt Widzenia). Ten kazus miał jednak bardziej złożone akcenty ${ }^{36}$. Skarżącym był członek wspomnianej organizacji, który $z$ niej formalnie wystąpił, a następnie uzyskał niemieckie obywatelstwo. Pracował on na lotnisku, gdzie - zgodnie $z$ ustawą

${ }^{32}$ BVerwG 6 A 4.02. Wyrok z 27 listopada 2002 r. dostępny na oficjalnej stronie Federalnego Sądu Administracyjnego: http://www.bverwg.de/entscheidungen/entscheidung.php?ent=271102U6A4.02.0 (dostęp: 16 grudnia 2013 r.).

${ }^{33} 1$ BvR 536/03 z 2 października 2003 r. Orzeczenie dostępne na oficjalnej stronie internetowej FTK: http://www.bundesverfassungsgericht.de/entscheidungen/rk20031002_1bvr053603.html (dostęp: 16 grudnia 2013 r.). Na stronie internetowej Trybunału FTK: http://www.bundesverfassungsgericht. de/entscheidungen.html dostępne są wszystkie jego wyroki wydane od $1998 \mathrm{r}$. Wcześniejsze najwygodniej jest zaczerpnąc $z$ jednego ze zbiorów orzeczeń, np. popularnego wydania D. Grimm, P. Kirchhof, Entscheidungen des Bundesverfassungsgerichts. Studienauswahl, t. 1-2, Tübingen 1997.

34 BVerwG 6 A 10.02. Wyrok z 3 grudnia 2004 r. dostępny na oficjalnej stronie internetowej Federalnego Sądu Administracyjnego: http://www.bverwg.de/ entscheidungen/entscheidung.php?ent=031204U6A10.02.0 (dostęp: 16 grudnia 2013 r.).

35 http://de.wikipedia.org/wiki/Al-Aqsa_\%28Verein\%29 (dostęp: 16 grudnia 2013 r.).

${ }^{36}$ Zob. A. Śledzińska-Simon, Prawa polityczne urzędników, Warszawa 2010, s. 290 . 
o komunikacji lotniczej (niem. Luftverkehrsgesetz) - dla poruszania się po niektórych częściach lotniska (dostępnych wyłącznie dla osób upoważnionych) musiał posiadać specjalne zaświadczenie o wiarygodności (niem. Zuverlässigkeit). Zaświadczenia tego, jako były członek Millî Görüş, nie otrzymał. Pracownik odwołał się do Bawarskiego Sądu Administracyjnego w Monachium, a następnie do Bawarskiego Trybunału Administracyjnego (pełniącego rolę wyższego sądu administracyjnego), wskazując na naruszenie swych praw podstawowych: godności osobistej, wolności od arbitralnego traktowania oraz swobody wyboru zawodu. Oba sądy podtrzymały jednak decyzję o legalności odmowy wydania zaświadczenia. Korzystne dla skarżącego rozstrzygnięcie przyniósł natomiast wyrok Federalnego Sądu Administracyjnego z 2004 r. ${ }^{37}$ Sąd uznał, że nie było podstaw dla odmowy wydania zaświadczenia, ponieważ organizacja, do której należał skarżący, nie realizuje celów wrogich konstytucji, a ponadto nie stosuje przemocy.

Na marginesie warto podkreślić, że niezależnie od delegalizacji niektórych stowarzyszeń czy organizacji, wzmożony nadzór nad ich działalnością roztacza od ponad dekady Urząd Ochrony Konstytucji (niem. Bundesamt für Verfassungsschutz) ${ }^{38}$. Przedmiotem zainteresowania tej agencji kontrwywiadu cywilnego jest m.in. działalność tzw. salafitów (arab. salaf-przodkowie), ortodoksyjnych czy raczej ultrakonserwatywnych muzułmanów. Salafici, których w RFN działa około 4-5 tys. ${ }^{39}$, postulują odrodzenie islamu przez powrót do jego źródeł. Na ulicach Niemiec, zwłaszcza Nadrenii Północnej-Westfalii

37 BVerwG 3 C 8.04. Wyrok z 11 listopada 2004 r. dostępny na oficjalnej stronie Federalnego Sądu Administracyjnego: http://www.bverwg.de/entscheidungen/pdf/111104U3C8.04.0.pdf (dostęp: 16 grudnia 2013 r.).

${ }^{38}$ Urząd działa na podstawie ustawy o ochronie konstytucji: Gesetz über die Zusammenarbeit des Bundes und der Länder in Angelegenheiten des Verfassungsschutzes und über das Bundesamt für Verfassungsschutz (Bundesverfassungsschutzgesetz) vom 27. September 1950 (BGBl. I, 682). Tekst jednolity z 20 grudnia 1990: BGBl. I, 2954, 2970.

${ }^{39}$ F. Ziehe, Islamisten sehen sich als Fremde und Verfolgte, „Schwäbisches Tagblatt“ 11 września 2010, http://www.tagblatt.de/Home/nachrichten/tuebingen_artikel,-Islamisten-sehen-sich-als-Fremde-und-Verfolgte-_arid, 111567. html (dostęp: 2 grudnia 2013 r.). 
oraz Hesji, rozdają Koran, a także organizują demonstracje, podczas których młodzi Niemcy przechodzą na islam ${ }^{40}$.

Urzędy ochrony konstytucji od kilku lat śledzą działalność salafitów. Władze samorządowe nierzadko odmawiają salafitom publicznego odprawiania modłów. Sądy z kolei nie raz uchylają te zakazy, wskazując na wolność sumienia i wyznania.

We wrześniu 2011 r. prokuratura w Kolonii wniosła przeciwko islamskiemu duchownemu Ibrahimowi Abou Nagiemu, działającemu w tym mieście, oskarżenie $z$ powodu publicznego podżegania (przez stronę internetową salafickiej organizacji Die Wahre Religion) do popełniania przestępstw i do zakłócenia pokoju religijnego. Postępowanie zostało umorzone w marcu 2013 r. z braku wystarczających dowodów ${ }^{41}$.

\section{Zakaz noszenia chust muzułmańskich}

\section{przez urzędniczki państwowe}

Problem noszenia w pracy chust (rodzaj hidżabów; niem. Kopftuch) przez muzułmańskie nauczycielki pojawił się w Niemczech przed kilkunastu laty. Należy w tym miejscu przypomnieć, że nauczyciele i nauczycielki mają w RFN status urzędników służby cywilnej, są mianowani, a jako przedstawiciele władzy państwowej cieszą się wysoką pozycją społeczną. $Z$ wymienionych powodów żąda się od nich pełnej lojalności, w szczególności godnego pełnienia urzędu, zaangażowania, utożsamiania się z państwem i jego demokratycznym porządkiem, politycznej neutralności ${ }^{42}$.

${ }^{40}$ K. Iskandar, Einen Koran in jeden Haushalt, „Frankfurter Allgemeine Zeitung“ 3 kwietnia 2012, http://www.faz.net/aktuell/politik/inland/salafisteneinen-koran-in-jeden-haushalt-11705989.html (dostęp: 2 grudnia 2013 r.).

${ }^{41}$ Peinliche Justiz-Posse um den Salafisten Abou-Nagie: Klage gegen HassPrediger muss eingestellt werden, https://www.focus.de/politik/deutschland/ peinliche-justiz-posse-um-den-salafisten-abou-nagie-klage-gegen-hass-prediger-muss-einstellt-werden_aid_738484.html (dostęp: 27 grudnia 2013 r.).

42 A. Śledzińska-Simon, op.cit., s. 19, 33, 122-123. Przeprowadzając szczegółowe analizy, autorka powołuje się m.in. na uchyloną już niemiecką ustawę ramową - Prawo urzędnicze (Rahmengesetz zur Vereinheitlichung des Beamtenrechts /Beamtenrechtsrahmengesetz/ vom 1. Juli 1957 z późn. zm.), która 
W związku z pracą urzędników niemieckie sądy od lat muszą zajmować się ważeniem dwóch konstytucyjnych wartości - zasad służby urzędniczej i wolności słowa ${ }^{43}$. Już w połowie lat 70 . XX w. FTK wydał słynne orzeczenie o radykałach ${ }^{44}$, w którym uznał zgodność ustawy urzędniczej Szlezwika-Holsztynu z ustawą zasadniczą i prawem federalnym, dopuszczając tym samym możliwość niezatrudniania kandydatów na urzędników, niedających gwarancji poszanowania demokratycznego porządku politycznego.

Głośny wyrok w sprawie noszenia przez nauczycielki islamskich chust w miejscu pracy (tzw. Kopftuchstreit) zapadł w 2003 r. Został on wydany niejednogłośnie ${ }^{45} \mathrm{i}$ miał - w pewnym sensie - zaskakującą konstrukcję prawną. Sprawa dotyczyła muzułmanki posiadającej obywatelstwo niemieckie, która starała się o posadę nauczycielki w państwowej szkole. Wyższy Urząd Szkolny (niem. Oberschulamt) w Stuttgarcie odrzucił w 1998 r. jej wniosek o zatrudnienie z powodu - jak uzasadnił - braku kwalifikacji osobistych. Otrzymaną decyzję administracyjną kobieta zaskarżyła do sądu administracyjnego w Stuttgarcie, a następnie - w toku instancji - do Trybunału Administracyjnego Badenii-Wirtembergii w Mannheim i wreszcie do Federalnego Sądu Administracyjnego (ówcześnie w Berlinie). Sądy oddaliły jej skargę. Po kilku latach procesów sprawa znalazła się w FTK. Ten 24 września 2003 r. wydał orzeczenie ${ }^{46}$ uchylające wyrok Federalnego Sądu Administracyjnego i przekazujące mu sprawę do ponownego rozpoznania. FTK dopatrzył się naruszenia praw podstawowych skarżącej, w szczególności jej zagwarantowanych konstytucyjnie prawa dostępu do urzędów publicznych (i to bez

została w 2009 r. zastąpiona nowymi ustawami: Bundesbeamtengesetz vom 5. Februar 2009 (BGBl. I, 160) oraz Gesetz zur Regelung des Statusrechts der Beamtinnen und Beamten in den Ländern vom 17. Juni 2008 (BGBl. I, 1010).

43 A. Śledzińska-Simon, op.cit., s. 139.

${ }^{44}$ BVerfGE 39, 333 z 22 maja 1975 r. (tzw. Radikalen-Entscheidung).

45 Zadecydowało pięciu sędziów; trzech zgłosiło votum separatum.

${ }^{46}$ 2BvR 1436/02 (orzeczenie dawniej zapisywane jako: BVerfGE 108, 282). Wyrok dostępny na oficjalnej stronie internetowej Federalnego Trybunału Konstytucyjnego: http://www.bundesverfassungsgericht.de/entscheidungen/ rs20030924_2bvr143602.html (dostęp: 28 grudnia 2013 r.). 
względu na wyznawaną religię) oraz wolności sumienia i wyznania ${ }^{47}$. Jednocześnie FTK wskazał, iż ewentualny zakaz noszenia chust w pracy przez nauczycielki musiałby mieć podstawę ustawową. Jeżeli jednak prawo krajowe (w tym wypadku badeńskie) tego nie zabrania, nauczycielka muzułmanka może nosić chustę w szkole. FTK nie zdobył się zatem na wydanie jednoznacznego orzeczenia oceniającego charakter muzułmańskiego nakrycia kobiecej głowy, czy określającego uprawnienie do noszenia chusty przez muzułmanki - urzędniczki służby cywilnej ${ }^{48}$.

Na takie dictum błyskawicznie zareagował ustawodawca Badenii-Wirtembergii. Już w 2004 r. wydano stosowny zakaz, nowelizując ustawę szkolną z 1983 r. (niem. Schulgesetz für Baden-Württemberg) i postanawiając, że w szkole nie wolno wyrażać zewnętrznie swych przekonań „politycznych, religijnych, światopoglądowych lub podobnych" 49 .

Rok 2009 przyniósł kolejne ważne orzeczenie sądowe w sporze o chusty, tym razem wydane przez Federalny Sąd Administracyjny w Lipsku ${ }^{50}$. Skargę do tej najwyższej instancji sądownictwa administracyjnego wniosła obywatelka Niemiec - mianowana dożywotnio nauczycielka, która przeszła na islam i postanowiła odwołać się od wyroku Trybunału Administracyjnego Badenii-Wirtembergii w Mannheim z 14 marca 2008 r. Jej skarga została jednak odrzucona. Federalny Sąd Administracyjny uznał, podobnie jak wcześniej sąd z Mannheim, że nauczycielka nie może zakładać chusty do pracy, ponieważ badeńska ustawa szkolna od 2004 r. nie pozwala pedagogom na manifestowanie $\mathrm{w}$ szkole swych poglądów religijnych.

${ }^{47}$ Gwarancje te zawiera odpowiednio art. 33 ust. $2-3$ oraz art. 4 ust. 1-2 ustawy zasadniczej.

${ }^{48}$ Zob. też J. Leffers, Kopftuch-Kontroverse: Kulturkampf in Karlsruhe „Spiegel Online" 24 września 2003, http://www.spiegel.de/unispiegel/studium/ kopftuch-kontroverse-kulturkampf-in-karlsruhe-a-266826.html.

${ }^{49}$ Ustawa dostępna na oficjalnej stronie internetowej Badenii-Wirtembergii: http://www.landesrecht-bw.de/jportal/?quelle=jlink\&query=SchulG+BW\&max =true (dostęp: 28 grudnia 2013 r.). Zob. jej § 38 .

${ }^{50}$ BVerwG2 B 46.08. Wyrok dostępny na oficjalnej stronie internetowej Federalnego Sądu Administracyjnego: http://www.bverwg.de/entscheidungen/ entscheidung.php?ent=161208B2B46.08.0 (dostęp: 28 grudnia 2013 r.). 
Sąd podkreślił w szczególności, że dopuszczony w praktyce wyjątek $\mathrm{w}$ postaci uprawnienia trzech sióstr zakonnych $\mathrm{z}$ Baden-Baden do noszenia habitów w jednej ze szkół podstawowych nie świadczy o uprzywilejowaniu religii chrześcijańskiej, lecz jedynie o poszanowaniu tradycji i historycznej roli tej jednej, konkretnej szkoły ${ }^{51}$.

\section{Dopuszczalność obrzezania chłopców}

Obrzezanie chłopców jest praktykowane w Niemczech wśród muzułmanów i Żydów. Jak się szacuje, dotyka ono tysięcy chłopców rocznie.

Problem obrzezania, jego karalności jako uszkodzenia ciała, ewentualnego uwzględnienia zgody rodziców jako okoliczności uchylającej bezprawność czynu, był nie raz przedmiotem dyskusji wśród prawników, zwłaszcza karnistów, a także orzecznictwa.

Szerokim echem odbił się w Niemczech wyrok sądu apelacyjnego w Kolonii z 2012 r. ${ }^{52}$ Został on wydany w związku ze sprawą lekarza z Kolonii, który w 2010 r. wykonał obrzezanie u czteroletniego chłopca. Zabieg spowodował komplikacje, chłopiec znalazł się w szpitalu, a ten ostatni zawiadomił prokuraturę. Sąd pierwszej instancji wydał wyrok uniewinniający lekarza, tym samym przyzwalając na obrzezanie. Prokuratura wniosła apelację. Sąd apelacyjny w Kolonii 7 maja 2012 r. uznał, że obrzezanie stanowi trwały

${ }^{51}$ Muslimische Lehrerin: Kopftuch im Unterricht bleibt verboten „Spiegel Online” 26 stycznia 2009, http://www.spiegel.de/unispiegel/jobundberuf/ muslimische-lehrerin-kopftuch-im-unterricht-bleibt-verboten-a-603617.html (dostęp: 28 grudnia 2013 r.). Na marginesie warto zauważyć, że wyrok Federalnego Sądu Administracyjnego odszedł tym samym od korzystnego dla nauczycielek muzułmanek rozstrzygnięcia sądu administracyjnego w Stuttgarcie z 2006 r., w którym stwierdzono, że kobiety mogą nosić w Badenii-Wirtembergii chusty muzułmańskie tak długo, jak długo siostry zakonne będą chodzić w habitach. Należy wreszcie dodać, że podobne do badeńskiego zakazy wprowadziły również dalsze landy.

${ }^{52}$ B. Hans, Landgericht Köln: Beschneidung aus religiösen Gründen ist strafbar, „Spiegel Online“ 26 czerwca 2012, http://www.spiegel.de/panorama/ justiz/religioes-motivierte-beschneidung-von-jungen-ist-laut-gericht-strafbara-841084.html (dostęp: 27 grudnia 2013 r.). 
uszczerbek na zdrowiu, nie może być usprawiedliwione względami religijnymi czy wolą rodziców, a ponadto narusza dobro dziecko, a zwłaszcza prawo dzieci do samookreślenia się co do religii, którą chcą wyznawać. Sąd podkreślił, że wprawdzie lekarz nie wiedział (sic!), że łamie prawo, ale obrzezanie jest czynem zabronionym.

Wyrok był przełomowy i natychmiast wzbudził liczne kontrowersje, wywołując wielką debatę społeczną. Oburzenie wyraziły organizacje żydowskie i muzułmańskie ${ }^{53}$. Już w połowie tego samego 2012 r. Parlament Federalny zobowiązał Rząd Federalny do przygotowania projektu ustawy pozwalającej - co do zasady - na obrzezanie chłopców. Od razu założono, że nie stanie się ona częścią kodeksu karnego. Ustawie nadano charakter cywilistyczny, konstruując odpowiedni, nowy przepis niemieckiego kodeksu cywilnego (niem. Bürgerliches Gesetzbuch - dalej: BGB).

Pod koniec 2012 r. Parlament Federalny uchwalił króciutką ustawę o zakresie opieki osobistej przy obrzezaniu chłopców ${ }^{54}$, zwaną powszechnie ustawą o obrzezaniu (niem. Beschneidungsgesetz). Ustawa wprowadziła do BGB - jego księgi czwartej „Prawo rodzinne" - punktu piątego poświęconego opiece rodzicielskiej (niem. elterliche Sorge) w rozdziale drugim, zatytułowanym „Pokrewieństwo" (niem. Verwandschaft) - nowy przepis w postaci $\S 1631 \mathrm{~d}$, który stanowi: „(1) Opieka osobista obejmuje także prawo udzielenia zgody na niekonieczne $z$ medycznego punktu widzenia obrzezanie chłopca, który nie jest zdolny do wyrażenia swej opinii i woli, o ile obrzezanie będzie przeprowadzone zgodnie $z$ wymogami sztuki lekarskiej. Zasada ta nie obowiązuje, jeśli obrzezanie, nawet

53 Umstrittener Gesetzentwurf: Opposition und Kinderschützer kritisieren Beschneidungsregeln, „Spiegel Online“ 27 września 2012, http://www.spiegel.de/ politik/deutschland/beschneidungs-gesetzentwurf-von-opposition-kritisierta-858285.html (dostęp: 27 grudnia 2013).

${ }^{54}$ Gesetz über den Umfang der Personensorge bei einer Beschneidung des männlichen Kindes vom 20. Dezember2012 (BGBl. I, 2749). Ustawa weszła w życie $z$ dniem 28 grudnia 2012 r. i jest dostępna na oficjalnej stronie internetowej: http://www.bgbl.de/Xaver/text.xav?bk=Bundesanzeiger_BGBl\& start=\%2F\%2F*[\%40attr_id\%3D\%27bgbl1 12061.pdf\%27]\&wc=1\&skin=WC\# Bundesanzeiger_BGBl_\%2F\%2F*[\%40attr_id\%3D\%27bgbl1 12061.pdf\%27] _1388682127212 (dostęp: 27 grudnia 2013 r.). 
zgodne $z$ celem, narusza dobro dziecka. (2) W okresie pierwszych 6 miesięcy od urodzenia dziecka obrzezanie, zgodne $z$ ustępem 1 , mogą analogicznie przeprowadzić także osoby przewidziane do tego przez wspólnotę religijną, o ile są do tego specjalnie przygotowane, chociaż nie są lekarzami” 55 .

Uchwalenie ustawy nie wygasiło dyskusji wokół obrzezania. Szczególnie ostro sprzeciwiają się jej nadal organizacje lekarskie i niektórzy karniści ${ }^{56}$. Przeprowadzone niedługo po wydaniu ustawy badanie opinii społecznej wykazało, że $24 \%$ społeczeństwa opowiada się za nową regulacją, natomiast aż 70\% jest jej zdecydowanie przeciwne $^{57}$.

W 2013 r. w interesującej nas sprawie wypowiedział się Wyższy Sąd Krajowy w Hamm (niem. Oberlandesgericht Hamm) - jedna z trzech wyższych instancji apelacyjnych w Nadrenii Północnej-Westfalii. Sąd ten 30 sierpnia 2013 r. wydał wyrok, w którym podtrzymał orzeczenie Sądu Rejonowego z Dortmund (niem. Amtsgericht Dortmund), wydane przez tzw. sąd rodzinny. W sprawie tej chodziło o sytuację sześcioletniego chłopca, którego pochodząca z Kenii matka, sprawująca nad nim wyłączną opiekę rodzicielską,

55 Tłumaczenie własne na podstawie internetowego wydania BGB - § 1631d: „Beschneidung des männlichen Kindes. (1) Die Personensorge umfasst auch das Recht, in eine medizinisch nicht erforderliche Beschneidung des nicht einsichts- und urteilsfähigen männlichen Kindes einzuwilligen, wenn diese nach den Regeln der ärztlichen Kunst durchgeführt werden soll. Dies gilt nicht, wenn durch die Beschneidung auch unter Berücksichtigung ihres Zwecks das Kindeswohl gefährdet wird. (2) In den ersten sechs Monaten nach der Geburt des Kindes dürfen auch von einer Religionsgesellschaft dazu vorgesehene Personen Beschneidungen gemäß Absatz 1 durchführen, wenn sie dafür besonders ausgebildet und, ohne Arzt zu sein, für die Durchführung der Beschneidung vergleichbar befähigt sind“, http://www.gesetze-im-internet.de/bgb/_1631d. html (dostęp: 16 grudnia 2013 r.).

${ }^{56}$ H. Putzke, Das Beschneidungsgesetz (§ 1631 d BGB) - Fauler Kompromiss und fatales Signal, „Monatsschrift Kinderheilkunde“ 2013, vol. 161, s. 950-951, http://www.holmputzke.de/images/stories/pdf/2013\%20MSchrKHK\%20 Putzke\%20Beschneidungsgesetz.pdf (dostęp: 27 grudnia 2013 r.).

${ }^{57}$ Infratest-Umfrage: Mehrheit der Deutschen gegen Beschneidungsgesetz, „Spiegel Online“ 22 grudnia 2012; http://www.spiegel.de/politik/deutschland/ studie-mehrheit-der-deutschen-gegen-beschneidungsgesetz-a-874473.html (dostęp: 27 grudnia 2013). 
chciała poddać obrzezaniu. Sąd uznał, że wprawdzie dziecko nie potrafi jeszcze podjąć samodzielnej decyzji co do swego obrzezania, ale norma prawna nakazuje rodzicom i lekarzowi odpowiednie omówienie $z$ dzieckiem planowanego zabiegu i uwzględnienie jego woli, czego w przedmiotowej sprawie nie było ${ }^{58}$.

\section{Podsumowanie}

Prawa imigrantów, w tym muzułmanów, są w Niemczech w znaczącym stopniu kształtowane nie tylko przez konstytucję i normy ustawowe, ale również przez orzecznictwo sądowe, zwłaszcza sądów administracyjnych i FTK. Działania legislacyjne podejmuje zarówno ustawodawca federalny, jak i ustawodawcy krajowi. Dotykają one problematyki islamu w niemieckiej przestrzeni publicznej, a co za tym idzie zagadnienia konstytucyjnego równouprawnienia religii. Sądy dostosowują swoje orzecznictwo do zmieniających się regulacji prawnych.

Przed sądami administracyjnymi i FTK wielokrotnie stawała ocena działalności islamskich organizacji religijnych. Po 11 września 2001 r. ułatwiono ich delegalizację, a zakazy funkcjonowania stowarzyszeń religijnych nie należą do rzadkości.

Sądy administracyjne, ustawodawcy krajowi oraz Federalny Trybunał Konstytucyjny wypowiedzieli się w ostatnim czasie w sprawie noszenia chust przez muzułmańskie nauczycielki zatrudnione w szkołach publicznych. Generalnie wprowadzono zakaz noszenia przez nie chust w ich miejscach pracy.

Zagadnienie obrzezania najpierw stawało przed sądami powszechnymi, lecz następnie wypowiedział się w tej kwestii ustawodawca. Chociaż sąd powszechny w głośnej sprawie powikłań po zabiegu obrzezania zakazał jego stosowania, ustawodawca wybrał przeciwny kierunek, zezwalając na rytualny zabieg medyczny. Co

58 Oberlandesgericht Hamm: Oberlandesgericht Hamm konkretisiert die neue Beschneidungsvorschrift (\$ 1631 d BGB), http://www.justiz.nrw.de/JM/ Presse/presse_weitere/PresseOLGs/25_09_2013/index.php (dostęp: 27 grudnia 2013 r.). 
ciekawe i charakterystyczne, nowej regulacji nie nadano charakteru prawnokarnego, lecz cywilnoprawny.

\section{STRESZCZENIE}

Jurysdykcja państwa niemieckiego w warunkach wielokulturowego społeczeństwa kilka wybranych przykładów ze szczególnym uwzględnieniem orzecznictwa administracyjnego i konstytucyjnego

Artykuł ukazuje współczesne Niemcy jako społeczeństwo wielokulturowe, w którym konflikty na tle religijnym czy obyczajowym są często rozwiązywane przez ustawodawcę i sądy. Największą grupę etniczno-religijną $\mathrm{w}$ Niemczech stanowią Turcy, dlatego problemy wynikające $z$ nakazów islamu oraz działalności organizacji muzułmańskich występują w praktyce najczęściej. W artykule przeanalizowano trzy wybrane problemy: zakazy działalności muzułmańskich związków religijnych, zakaz noszenia islamskich chust przez nauczycielki zatrudnione w szkołach publicznych oraz ustawowe zezwolenie na zabiegi obrzezania, także takie wykonywane przez osoby niebędące lekarzami.

Słowa kluczowe: Niemcy współczesne, wielokulturowość, orzecznictwo sądów niemieckich, islamskie związki religijne, chusta islamska, obrzezanie.

\section{SUMMARY}

Jurisdiction of the German State in a multicultural society under special consideration of the administrative case-law and constitutional jurisprudence

The article presents the contemporary Germany as a multicultural society in which the conflicts on the religious or moral background are often solved by a legislature and courts. The largest religious and ethnic group are Turks, therefore the problems, which actually appear the most frequently, are connected with the Islamic injunctions or with the activity of Islamic religious associations. The article elaborates on the three selected issues: bans on activity of Islamic religious associations, prohibition to wear 
Islamic headscarves by teachers in public schools and the statutory authorization for the circumcision procedure which does not have to be conducted by a doctor.

Keywords: contemporary Germany, multiculturalism, case-law of the German courts, Islamic religious associations, Islamic headscarf, circumcision.

\section{BIBLIOGRAFIA}

Banaszak B., Bernaczyk M., Aktywizm sędziowski we współczesnym państwie demokratycznym, Warszawa 2012.

Banaszak B., Malicka A., Konstytucja Niemiec, Warszawa 2008.

Banaszak B., Sacownictwo konstytucyjne a ochrona podstawowych praw obywatelskich. RFN, Austria, Szwajcaria, Wrocław 1990.

Banaszak B., Żukowski Ł., System środków ochrony praw podstawowych $w$ RFN, „Przegląd Sejmowy” 2009, nr 6.

Buras P., Z islamem krzyż pański, „Gazeta Wyborcza” 30-31 maja 2009.

Czarny P., Federalny Trybunat Konstytucyjny i ewolucja jego polityczno-ustrojowego znaczenia w Niemczech i Europie, „Przegląd Sejmowy” 2009, nr 6.

Denninger E., Freiheit durch Sicherheit? Anmerkungen zum Terrorismusbekämpfungsgesetz, http://www.bpb.de/publikationen/32OUOD,0,Freiheit_durch_Sicherheit.html (dostęp: 16 grudnia 2013 r.).

Derlatka M., Skarga konstytucyjna w Niemczech, Warszawa 2009.

Garlicki L., Federalny Trybunał Konstytucyjny $w$ Republice Federalnej Niemiec, w: Trzciński J., Sądy konstytucyjne $w$ Europie, t. 1: Austria, Francja, Niemcy, Wtochy, Warszawa 1996.

Gelles K., Kozerski M., Społeczeństwo wielokulturowe $w$ Niemczech $w$ opinii przedstawicieli niemieckich partii politycznych, „Niemcoznawstwo” 2008, nr 16.

Grimm D., Kirchhof P., Entscheidungen des Bundesverfassungsgerichts. Studienauswahl, t. 1-2, Tübingen 1997.

Hans B., Landgericht Köln: Beschneidung aus religiösen Gründen ist strafbar, „Spiegel Online“ 26 czerwca 2012 r., http://www.spiegel.de/panorama/ justiz/religioes-motivierte-beschneidung-von-jungen-ist-laut-gerichtstrafbar-a-841084.html (dostęp: 27 grudnia 2013 r.).

Iskandar K., Einen Koran in jeden Haushalt, „Frankfurter Allgemeine Zeitung“ 3 kwietnia 2012, http://www.faz.net/aktuell/politik/inland /salafisten-einen-koran-in-jeden-haushalt-11705989.html (dostęp: 2 grudnia 2013 r.). 
Janicka D., Ustawa zasadnicza $w$ praktyce Republiki Federalnej Niemiec (1949-1989), Toruń 2009.

Leffers J., Kopftuch-Kontroverse: Kulturkampf in Karlsruhe „Spiegel Online” 24 września 2003, http://www.spiegel.de/unispiegel/studium/kopftuch-kontroverse-kulturkampf-in-karlsruhe-a-266826.html.

Nita B., Skarga konstytucyjna $w$ Republice Federalnej Niemiec ( $w$ świetle danych statystycznych oraz orzecznictwa niemieckiego Federalnego Trybunału Konstytucyjnego), „Przegląd Sejmowy” 2001, nr 2.

Papier H.J., Das Bundesverfassungsgericht als Anreger und Hüter der Verfassungsentwicklung, w: Festschrift für Winfried Hassemer, red. F. Herzog, U. Neumann, Heidelberg 2010.

Putzke H., Das Beschneidungsgesetz (§ 1631 d BGB) - Fauler Kompromiss und fatales Signal, „Monatsschrift Kinderheilkunde“ 2013, vol. 161.

Śledzińska-Simon A., Prawa polityczne urzędników, Warszawa 2010.

Ustawa zasadnicza (konstytucja) Republiki Federalnej Niemiec z 23 maja 1949 r.: wersja niemiecka i polska z uwzględnieniem wszystkich kolejnych zmian, red. L. Janicki, tłum. J. Koprucka-Purolowa., B. Demby, Poznań 2007.

Wieliński B.T., Islamscy sędziowie w Niemczech, „Gazeta Wyborcza” 2 września 2011.

Ziehe F., Islamisten sehen sich als Fremde und Verfolgte, „Schwäbisches Tagblatt“, 11.09.2010. http://www.tagblatt.de/Home/nachrichten/ tuebingen_artikel,-Islamisten-sehen-sich-als-Fremde-und-Verfolgte-_ arid,111567.html (dostęp: 2 grudnia 2013 r.). 
